\section{Autorefleksyjność współczesnych nauk humanistycznych i co powinno z tego wynikać}

Anna Łebkowska
$\mathbf{T}$ rudno nie zauważyć, że chętnie posługujemy się dziś określeniem refleksja humanistyczna, co więcej, zdążyło się już ono zadomowić się we współczesnym słowniku. Żeby nie być gołosłowną, oto kilka przykładów: jedna z konferencji zorganizowanych niedawno przez Instytut Badań Literackich PAN nosiła tytuł: Refleksja humanistyczna w planowaniu przestrzennym (jesień 2015), z kolei u Michała Pawła Markowskiego czytamy o „humanistyce jako [...] dyspozycji refleksyjnej"', co - rzecz jasna - nie brzmi identycznie, ale sama refleksyjność zajmuje istotne miejsce; $u$ Januszkiewicza: „[j]eżeli wierzę w ważność humanistyki, to mam na myśli ten typ refleksji, który towarzyszyć chce temu, co nazywamy conditio humana”2. Dla Roberta Piłata „humanistyka jest refleksją,

1 M.P. Markowski Humanistyka, literatura, egzystencja, w: Teoria literatura życie. Praktykowanie teorii w humanistyce współczesnej, red. A. Legeżyńska, R. Nycz, Wydawnictwo IBL PAN, Warszawa 2012, s. 20. Por. też tegoż Polityka wrażliwości. Wprowadzenie do humanistyki, Kraków 2013.

M. Januszkiewicz Czy mamy dziś kryzys humanistyki?, "Znak" 2009 nr $\mathrm{X}$ : Bankructwo humanistyki, s. 79.

\section{Anna}

Łebkowska - prof. dr hab. Wydział Polonistyki UJ. Główne kierunki zainteresowań naukowych: badanie literatury w perspektywie antropologii kulturowej, empatia jako antropologiczna kategoria literatury, kategoria cielesności; teorie fikcji literackiej; literatura XXiXXI wieku. Autorka książek: Fikcja jako możliwość (1998); Między teoriami a fikcją literackq (2001); Empatia. O literackich narracjach przełomu XXi XXI wieku (2008). Redaktor Naczelna „Ruchu Literackiego". 
której przedmiot stanowi s a ma refleksyjn a is t o ta"3. U każdego z wymienionych autorów określenie takie zostało użyte nie tylko z premedytacją, ale też z konkretnym i dobitnym uzasadnieniem. Zjawisko jest jednak szersze. I choć - jak to zwykle bywa przy nadmiernej ekspansywności danego terminu - zaczyna niekiedy sprawiać wrażenie automatyzmu językowego, jednakże z reguły użycie słowa refleksja nie jest bezrefleksyjne.

Jego współczesnej obecności sprzyja - jak sądzę - kilka powodów. Przede wszystkim: określenie to trafnie oddaje typ namysłu i rodzaj przemian, jakie nastąpiły we współczesnej humanistyce. Pozwala bowiem zasygnalizować po pierwsze, jej transdyscyplinarny charakter: przy czym można go użyć zarówno dla jej zagadnień w ogólności bez wyznaczania jakichś ścisłych granic, jak i stosować w sensie węższym, niejako synekdochicznym. Po drugie, pozwala na wyminięcie takich pojęć jak dyskurs; po trzecie zwalnia z używania słów w rodzaju dyscyplina czy nauka. Otwiera tym samym drzwi prowadzące w stronę takiego ujmowania humanistyki, które nie zrównuje jej z nauką w sensie twardym. Po czwarte, odsuwa, a właściwie likwiduje pytanie o tak rozumianą użyteczność, która jest utożsamiana z bezpośrednią przydatnością pojmowaną w wąskim, ściśle pragmatycznym sensie, jako co najmniej niestosowne. (Do zagadnienia trzeciego i czwartego jeszcze wrócę). Po piąte, refleksja z założenia implikuje poziom meta ${ }^{4}$, zatem pociąga za sobą wymiar autokrytyczny. W tym wymiarze zaznacza się pamięć o połączeniu nauk humanistycznych (w sensie Diltheyowskim) z ideami nowoczesności w ich najciemniejszej tonacji. Nie chodzi mi tu wyłącznie o dobrze znane, wskazane przez Foucaulta, a także przez Derridę, Isera, Gumbrechta, Toulmina czy Agambena negatywne przekształcenia myśli oświeceniowej ${ }^{5}$, ale także o zwyrodniałe tendencje czerpiące bezpośrednio z założeń przełomu antypozytywistycznego. Przypomnieć tu można artykuł Stefanii Skwarczyńskiej Od Diltheya i nurtów neoidealistycznych do nazistowskiej nauki o literaturze $e^{6}$. Dzisiejsza refleksja humanistyczna ma bardzo dużą świadomość tego typu niebezpieczeństw. Między innymi obawia się tego, z czego była

3 R. Piłat Uniwersytet i aspiracje humanistyki, www..filozofia.org.pl/wu/resources/Artykuly/Uniwersytet-i-aspiracje humanistyki.

4 Szerzej na ten temat tamże.

5 W tym miejscu można dodać jeszcze jeden głos, mianowicie Rosi Braidotti, która w swojej książce Po człowieku, przeł. J. Bednarek, A. Kowalczyk, PWN, Warszawa 2014 właściwie zrównuje humanizm z ideami oświecenia

6 S. Skwarczyńska Kierunki w badaniach literackich, PWN, Warszawa 1984. 
swego czasu dumna, mianowicie: antropocentryzmu (zwłaszcza w perspektywie wskazanego przez Agambena nazistowskiego podziału na ludzkie i nie-ludzkie).

Innymi słowy, autorefleksja zakłada odwagę polegającą na krytykowaniu własnych podstaw. I wreszcie, po szóste, jako swoje wyznaczniki przyjmuje otwartość i brak stagnacji: krytycznie interpretuje, wyprzedza, dogania7, reaguje na lęki współczesności, zarazem je dostrzega i wyławia, wyznacza wciąż nowe obszary, nie porzucając dotychczasowych: odnawia duchowość, wskazując na nieuniknione zależności między afektem a intelektem, cielesnością i umysłem itd. i wreszcie przekracza konstruktywizm, zmierzając w stronę rzeczy: materii i empirii. Za Markowskim można dopowiedzieć:

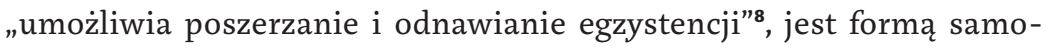
kształcenia9 ${ }^{\mathrm{i}}$, jak chce Nycz, a trudno tu się z jego poglądami nie zgodzić: innowacyjności.

Owa refleksyjność nie odbiera jej jednak - jak twierdzę - naukowości. Innymi słowy: w dalszym ciągu jest nauką, acz rzecz jasna, w innym sensie niż nauki ścisłe. Jej odrębność pozostaje w mocy. Choć, gdyby sięgnąć do kryteriów różnicujących, będą one inne niż w czasach przełomu antypozytywistycznego. Nie wnikając w tej chwili w tego typu klasyfikacje, po wielokroć ostatnio już dyskutowane, i kierując się ku przekonaniu, że mamy do czynienia ze zbiorem nauk słabych (w sensie Vattimowskim), należy stwierdzić, że właśnie owa autorefleksyjność stanowi siłę napędową nauk humanistycznych. Można by zatem wysnuć z tej sytuacji wniosek, że powinno być znakomicie. Dlaczego zatem nauki humanistyczne są tak chętnie pomawiane o kryzys, dyskredytowane czy wręcz atakowane?

Ostatnie lata dosyć dobitnie pokazują, że w mniejszym stopniu w grę wchodzi tu spór między naukami ścisłymi i humanistycznymi. Choć rzeczywiście drogi się tu niekiedy nieco nadmiernie rozchodzą, a wzajemna wiedza nauk o sobie polega na ignorancji, trochę tak, jak u Hellera wypominającego przed laty Tischnerowi, co następuje: „naszym zasadniczym [...] punktem niezgody był stosunek do nauk przyrodniczych. Tischner chętnie wprowadzał rozróżnienie sceny i dramatu (lub filozofii sceny i filozofii dramatu). Dramat rozgrywa się na scenie, ale scena nie bierze

\footnotetext{
7 O tym jak „teoria nauk humanistycznych dogania zmiany w świecie” patrz E. Domańska Zwrot performatywny we współczesnej humanistyce, "Teksty Drugie” 2007 nr 5, s. 53 i n.

8 M.P. Markowski Polityka wrażliwości..., s. 74, 75.

9 M.P. Markowski Humanistyka, literatura, egzystencja, w: Teoria literatura życie.., s. 39.
} 
w nim bezpośredniego udziału. Scenę tworzą nauki przyrodnicze, ale nie uczestniczy ona w dramacie". Dla Hellera ta sytuacja była powodem do ubolewania ${ }^{10}$.

A co więcej - rozwijając wątek wzajemnej nieufności - to właśnie po stronie nauk humanistycznych pojawia się niebezpieczne rozróżnienie traktujące nauki ścisłe jako twarde: otóż nauki te niekoniecznie chcą być takimi (to tak, jakbyśmy np. logikę ograniczyli wyłącznie do logiki formalnej). Ponadto pojawiają się tu spory jeszcze innego rodzaju: trudno w tym miejscu nie przypomnieć słynnego konfliktu, najpierw uobecnionego w latach 6o. w książce Snowa, który widział nauki humanistyczne jako dominujące w sposób nieuprawniony nad ścisłymi, i kilkadziesiąt lat później odrodzonego w ostrzejszej formie w wydanej w 1995 roku książce Brockmana Trzecia kultura" ${ }^{11}$. Autor z aprobatą ogłasza w niej, że świat nauki (= świat nauk ścisłych) staje się jedynym źródłem paradygmatu kulturowego ${ }^{12}$, a jej przedstawiciele mogą odgrywać rolę autorytetów, wskazywać właściwe rozwiązania, wypierając nauki humanistyczne.

Niewątpliwie zarówno te już nieco zadawnione konflikty, jak i trwająca przez sporą część XX wieku troska o separację poszczególnych dyscyplin, do tej sytuacji w sposób oczywisty się przyczyniły. Jednakże obecnie nie podlega kwestii fakt następujący: otóż współczesne relacje między naukami ścisłymi i humanistycznymi mają inny charakter.

Gdyby zapytać o to, jak dziś wygląda sytuacja, mimo wszystko należałoby powiedzieć, że nauki ścisłe funkcjonują w symbiozie z humanistycznymi, choć jest to symbioza w nowej postaci: nie ulega bowiem wątpliwości rola kognitywistyki, neurobiologii, nowych technologii, znaczenie badań poświęconych relacjom między tym, co ludzkie i nie-ludzkie, sztuczne, zwierzęce (termin naturakultura pisany łączne też tę sytuację poświadcza). Istotne miejsce zajmują nowe powiązania między humanistyką i naukami o życiu, neowitalizm czy zwrot w stronę rzeczy, a tym samym w stronę materialności i empirii, otwierają się nowe zadania przed medycyną i fotografią, zwłaszcza

10 J. Heller WI rocznicę śmierci Józefa Tischnera, "Magazyn Kulturalny Tygodnika Powszechnego" $8 \mathrm{VII} 20017 / 8(56 / 57)$.

11 Trzecia kultura, red. ). Brockman, przeł. P. Amsterdamski i in., CIS, Warszawa 1996 (wersja oryg. 1995).

12 O tym Kluszczyński w artykule Trzecia kultura. O współczesnych zwiq̨zkach sztuki, w: „Przegląd Kulturoznawczy" 2011 nr 1 (9), s. 37, o niebezpieczeństwach trzeciej kultury zob. też R. Piłat Uniwersytet... 
jako zadania dla forensyki ( - o tym pisze prof. Sendyka). Pomijam humanistykę cyfrową, ponieważ to odrębny temat. A zatem, wracając do Tischnera, można z pełnym przekonaniem powiedzieć: scena i dramat zaczynają funkcjonować na równych prawach i żywimy nadzieję, że korzyści będą tu obopólne. Różnica tkwi jeszcze w czymś innym. Wystarczy porównać pierwszą połowę XX wieku z czasami współczesnymi. Wówczas najnowsze teorie w dziedzinie fizyki: przestrzeń zakrzywiona, teoria kwantów, teoria względności współgrały z przemianami narracji w literaturze, takimi jak zwłaszcza technika i teoria punktów widzenia. Tego typu powiązań w samej literaturze i, ogólniej, w sztuce jest jakby mniej. Znamy też odpowiedź: epistemologia znalazła się w odwrocie, nie wspominając już o ontologii (ze względu na brak kompetencji nie ośmielę się powiedzieć, że być może zmniejszyła się ilość atrakcyjnych - zmieniających sposób myślenia o świecie - teorii w dziedzinie np. fizyki). Z kolei literatura hipertekstowa, którą można by tu podsunąć jako współczesną wersję tego typu współbieżności, ma jednak inną genezę: gdy tam można było doszukiwać się paraleli, tu należałoby mówić po prostu o bezpośrednim wykorzystaniu najnowszych technologii.

Trzeba jeszcze zaznaczyć, że zwłaszcza ostatnimi czasy przedstawiciele nauk ścisłych (tzw. podstawowych) i nauk humanistycznych niekiedy wyjątkowo mocno się wspierają. Tu zresztą można przypomnieć Marthę Nussbaum, która w ramach specyficznej dla siebie koncepcji humanistyki powiada

nie przeczę, że nauki ścisłe i nauki społeczne - zwłaszcza ekonomia odgrywają w edukacji obywatelskiej ważną rolę. Nikt jednak nie postuluje, by te nauki porzucać [...] w swoim najlepszym wydaniu wszystkie te dziedziny przesiąknięte są czymś, co możemy nazwać duchem humanistyki poszukują krytycznego i odważnego myślenia empatycznego, zrozumienia rozmaitych doświadczeń, będących udziałem człowieka, a także rozumienia złożoności świata, w którym żyjemy. ${ }^{13}$

Podsumowując: wszystko wskazuje na to, że na tym polu idzie ku lepszemu.

Nie ulega też wątpliwości, że największe zagrożenie ujawnia się nie w sporze między naukami ścisłymi - w ich podstawowym sensie - i humanistycznymi, ale w upraszczająco rozumianej praktyczności, użyteczności, w sprowadzeniu nauk uniwersyteckich do przygotowania do zawodu, w nastawieniu

13 M. Nussbaum Nie dla zysku. Dlaczego demokracja potrzebuje humanistów, przeł. Ł. Pawłowski, Fundacja Kultura Liberalna, Warszawa 2016. 
na zysk (znowu: jakby powiedziała Nussbaum) i wreszcie w traktowaniu uniwersytetu jako instytucji usługowej, a nauki jako towaru. Dobrze o tym wiemy i dokładamy wszelkich starań, żeby temu zapobiec. Nie jest też moim celem powtarzanie tych znanych problemów.

Zmierzam do innych kwestii: otóż oprócz finansowania nauki, oprócz działań rynkowych, oprócz nagonki medialnej i niekompetentnych wypowiedzi dziennikarzy pojawia się - i to mnie bodaj najbardziej zaskakuje niechęć, by tak się wyrazić - całkowicie bezinteresowna płynąca nie ze strony tych, którzy czyhają na granty czy wyższe pensje, nie ze strony tych, którzy wiedząc, że kołdra jest za krótka, chcą zadbać o korzystny dla nich podział budżetu itd., ale ze strony tych, którym tego rodzaju problemy - mogłoby się wydawać - powinny być niejako z założenia obojętne. Jest bowiem zastanawiające, z jaką satysfakcją przekazuje się nam informacje o zamykaniu wydziałów humanistycznych na japońskich uniwersytetach, o bezrobotnych humanistach; jak mimochodem, ale często podkreśla się naszą zbędność (nie tylko w mediach, ale też w zwykłych kontaktach międzyludzkich).

Od razu odpowiadam na spodziewane i słuszne zarzuty: oczywiście, nie zawsze i nie wszyscy tak czynią. Wiadomo też, że zainteresowanie humanistyką ostatnio nieco się zwiększa (i oby tak dalej), że są tacy, którzy ją doceniają itd. Niemniej, zjawisko tego rodzaju zaznacza się wciąż wyraźne, w szerokim społecznym odczuciu często jesteśmy traktowani jako niepotrzebni. Na początek chcę zaznaczyć: odpowiedź sprowadzająca się do stwierdzenia, że ci niechętni zostali już zmanipulowani (przez media itd.), nie wydaje mi się wystarczająca.

Nie zamierzam jednak popadać ani w jeremiady, ani w laudację. Uważam, że mimo obecnego stanu nauk humanistycznych, już rozpoznanego, opisanego i słusznie zdiagnozowanego - a także mimo że sytuacja nieco się poprawia - są jednak powody do bicia się w piersi, choć być może należy czynić to po cichu, by nie dostarczać argumentów przeciwnikom.

Otóż, po pierwsze: pewne formy izolacji nauk humanistycznych, i to niestety zawinione przez ich przedstawicieli, trwały zbyt długo. Za mało było działań upowszechniających, za mało aktywności po prostu popularyzatorskiej. Myślę tu o braku czy o niewystarczającej liczbie inicjatyw przybliżających w najprostszym znaczeniu tego słowa: np. objaśniających najnowsze teorie, nowe tendencje. Tym różniliśmy się od zachodu jeszcze w czasach PRL-u, ale też po 1989 roku (choć zdaję sobie sprawę, że kryzys nauk humanistycznych dotyczy obecnie całego świata). Otóż tam niemal od razu najnowsze teorie, pojęcia, terminy (nawet te najtrudniejsze) znajdywały się 
i znajdują nadal w opracowaniach, słownikach, antologiach najważniejszych tekstów i niekoniecznie drogich seriach wydawniczych. Teraz sytuacja zmienia się na korzyść, ale dopiero w efekcie malejącej liczby studentów. Należało zadbać o to wcześniej. A zatem - ciągle jeszcze zbieramy pokłosie izolacji i braku upowszechniania, zwłaszcza nieco bardziej skomplikowanych myśli współczesnej humanistyki. Tu przykład: Hans Ulrich Gumbrecht, jeden z najwybitniejszych dzisiejszych humanistów, powiada ${ }^{14}$ tak oto: „akademicka humanistyka to jałowe nudziarstwo i, poza działami kulturalnymi wielkich gazet, mało kto by zauważył zamknięcie wydziałów humanistycznych"15. Jednak właśnie Gumbrecht - uniwersytecki profesor propagator istotnych dla dzisiejszej humanistyki pojęć: latencja i stimmung/nastrój, może sobie pozwolić na taką ironię, jego książki docierają bowiem do bardzo szerokiego grona odbiorców.

Jednakże nie tylko o promocję mi chodzi i nawet nie tylko o upowszechnianie, choć nigdy dość dbałości o tego typu działania. Otóż, po pierwsze, jedną z nowych możliwości widzę w badaniu - tu użyję określenia anachronicznego i nie do końca stosownego - inicjatyw oddolnych, mianowicie flashmobów, forów czytelniczych, blogów krytycznoliterakich, literackich klubów fanowskich, fanfikcji, różnego rodzaju działań, niekiedy grupowych, niekiedy indywidualnych, czasem dopiero się zaznaczających, czasem już utrwalonych, przybierających formę nowych postaci bycia wobec sztuki i uczestniczenia w niej.

Myślę także o tym, co Ewa Rewers nazwała „praktyką artystyczną jako produkcją wiedzy"16, a zarazem także o badaniu takich praktyk artystycznych, np. w wymiarze internetowym. Cały ten obszar społecznej inwencji na szczęście zaczyna być już uwzględniany i miejmy nadzieję, nie umknie naszej humanistycznej wrażliwości. Oczywiście z premedytacją odwołuję się do wrażliwości, by nie używać określenia pole widzenia, skażonego postawą dominującą. Zmierzam tym samym do następnego punktu.

Mianowicie, po drugie, wciąż daje o sobie znać współczesne narcystyczne ego humanisty. Pamiętajmy, że jeśli jeszcze w roku 1960 Ingarden pisał, że

14 Jeśli wierzyć autorowi wstępu do książki Po roku 1945. Latencja jako źródło współczesności wydanej w 2012 roku, a w tłumaczeniu polskim w roku 2015, Adamowi Krzemińskiemu.

15 A. Krzemiński Wstęp do H.U. Gumbrecht Po roku 1945. Latencja jako źródło współczesności, przeł. A. Paszkowska, Wydawnictwo Krytyki Politycznej, Warszawa 2015.

16 E. Rewers Praktyka jako badanie: nowe metodologie w humanistyce, w: Teoria literatura życie..., s. 60 . 
w chwili obcowania z jakościami metafizycznymi w trakcie lektury dzieła literackiego „odsłania się nam głębszy sens życia i bytu w ogóle, [...] przy ich ujrzeniu odsłaniają się nam głębie i praźródła bytu, na które - zwykle jesteśmy ślepi i których istnienie w codziennym życiu zaledwie przeczuwamy"17 i „sztuka może nam dać poprzez uchwycenie i dystans spokojną (ich) kontemplację ${ }^{18}$, to stwierdzenie takie z góry niejako dawało badaczom literatury dosyć duże poczucie bezpieczeństwa. Wszak nie kto inny tylko oni właśnie byli do takiego odbioru dzieła najlepiej przygotowani. Obecnie bezpieczeństwo tego rodzaju straciliśmy (zwrot postsekularny, jak dotąd, jest zbyt hybrydyczny, żeby można w nim upatrywać ponownej sakralizacji sztuki). Zauważalna we współczesnych tekstach pewna wyniosłość zdaje się stamtąd czerpać, przy - bądź co bądź - innym już ujmowaniu sztuki, jej miejsca, roli w odczuciu społecznym. Dlatego też dzisiejsze ego humanisty funkcjonuje niekiedy trochę na zasadzie powidoku: barwy już inne, ale kształt jakby ciągle ten sam. Na marginesie: zarzut wyniosłości humanizmu jest zresztą dzisiaj dostrzegany i opisywany, choć w innym wymiarze, np. - w założeniach posthumanizmu u Braidotti1 ${ }^{19}$. Co zresztą nie przeszkadza jej żywić przekonania, że posthumanizm walnie przyczynia się do rozwoju nauk humanistycznych.

Po trzecie, bodaj najtrudniejsze i powiązane z poprzednim, a mianowicie: przedstawiciele współczesnej refleksji humanistycznej z pełną świadomością starają się unikać autorytaryzmu, można by przecież bez zbytniej przesady stwierdzić, że przemiany ostatnich kilku dekad są efektem troski tego rodzaju, jednak mimo wszystko ów pouczający ton sprawia wrażenie powracającego (zwłaszcza w przypadku humanistyki zaangażowanej). Owa postawa wyższości została już zresztą dostrzeżona i omówiona w odniesieniu np. do sztuki krytycznej ${ }^{20}$. Innymi słowy, nawet tam, gdzie z założenia unika się autorytaryzmu i podporządkowania nauk humanistycznych politycznym ideologiom, i tak może pojawić się niebezpieczny protekcjonalizm.

17 R. Ingarden O dziele literackim: badania z pogranicza ontologii, teorii języka i filozofii literatury, PWN, Kraków 1960, s. 369. Nie zmienia sytuacji to, że Das literarische Kunstwerk ukazało się W 1931 roku.

Tamże, s. 372.

Która, o czym już wspominałam - w sposób jednoznaczny utożsamia humanizm nie tylko z ideałami oświecenia, ale także z uniwersalizmem eurocentrycznym.

I. Kowalczyk Polska sztuka krytyczna - próba podsumowania, Materiały prasowe Centrum Sztuki Współczesnej Zamek Ujazdowski; „British, British, Polish, Polish”; „Sztuka krańców Europy długie lata 90 i dziś". Tu właśnie pojawia się określenie: protekcjonalizm. 
Właściwie znamy odpowiednią drogę: prowadzi ona przez wrażliwość, współbycie empatię, solidarność (o której za Rorty'm mówił Michał Paweł Markowski w trakcie VI Światowego Kongresu Polonistów), współuczestnictwo, które mają zlikwidować sidła politycznych ideologii. Tu krótka uwaga: otóż wskazywana przez Markowskiego (znowu za Rorty'm) zasada solidarności, opisywania siebie i świata wciąż od nowa, jest jednak o tyle niebezpieczna, że w tle wyłania się zakładana niejako implicite przez filozofa jego heroiczna i chyba nieco utopijna wiara w wewnętrzne dobro człowieka. Ale - co najważniejsze i z czym trudno się nie zgodzić - Rorty przyjmuje, że wciąż nowe opisy najlepiej realizuje sama sztuka, a zwłaszcza literatura. Jako badacze możemy nie tyle budować znów swoje ego (choć to oczywiście kuszące), ile wciąż wskazywać na odkrywany przez nas jej potencjał. Innymi słowy, powinniśmy z pomocą refleksyjno-krytycznej świadomości nie gubić takiej drogi, która pozwala unikać Scylli narcyzmu i Charybdy protekcjonalizmu. Niewątpliwie starania te warte są podejmowania wciąż od nowa.

\section{Abstract}

\section{Anna Łebkowska}

JAGIELLONIAN UNIVERSITY (CRACOW)

The Humanities'Self-Referentiality and Its Possible Implications

Łebkowska examines the notion of humanistic thought - its role and its roots - as it functions today. She focuses on its advantages, highlighting especially the self-critical aspect, but at the same time looking for the reasons behind the humanities' current situation. She also points out phenomena that have been neglected in this selfreferential stance. In her conclusion Łebkowska touches on the problematic relationship between the objects of research and the'usefulness,' 'useability' and the'responsibilities' of the humanities.

\section{Keywords}

literature, humanities, self-referentiality,'third culture' 